\title{
EFFECTS OF THE SYNTHETIC ESTROGEN 17 $\alpha$-ETHINYLESTRADIOL ON THE LIFE-CYCLE OF THE FATHEAD MINNOW (PIMEPHALES PROMELAS)
}

\author{
Reinhard Länge, ${ }^{*} \dagger$ Thomas H. Hutchinson, $\$$ Charlotte P. Croudace, \\ Hermann Schweinfurth $\uparrow$ Peter Hampe, $\nmid$ Grace H. Panter, $\ddagger$ and John P. Sumpter $\S$ \\ †Experimental Toxikologie, Schering AG Research Laboratories, D-13342 Berlin, Germany \\ $\ddagger$ Brixham Environmental Laboratory, AstraZeneca, Freshwater Quarry, Brixham, Devon TQ5 8BA, United Kingdon \\ §Department of Biology and Biochemistry, Brunel University, Uxbridge, Middlesex UB8 3PH. United Kingdom
}

\begin{abstract}
A fish full life-cycle (FFLC) study was conducted for $17 \alpha$-ethinylestradiol $\left(\mathrm{EE}_{2}\right.$ ) using the fatheal minnow, Pinephales promelas. Newly fertilized embryos ( $<24 \mathrm{~h}$ old) were exposed to five concentrations of $\mathrm{EE}_{2}(0.2,1.0,4.0,16$, and $64 \mathrm{ng} / \mathrm{L}$ nominal in continuous flow-through conditions for $305 \mathrm{~d}$ at $25 \pm 1^{\circ} \mathrm{C}$. Exposure concentrations were verified by ${ }^{14} \mathrm{C}-\mathrm{EE}_{2}$ radiochemistry, supported by radioimmunoassay, and mean measured values were $\geq 70 \%$ of nominal. For the $\mathrm{F}_{0}$ adult phase until $301 \mathrm{~d}$ posthatch, the no-observed-effect concentrations (NOECs) for growth, survival, and reproduction (as egg production) were all $\geq 1.0 \mathrm{ng} / \mathrm{L}$. The NOEC values for $F_{1}$ embryo hatching success and Iarval survival (at $28 \mathrm{~d}$ posthatch) were both $\geq 1.0 \mathrm{ng} / \mathrm{L}$. While statistically detectable changes in $F_{1}$ growth were evident at $0.2 \mathrm{ng} / \mathrm{L}$, these were not considered to be biologically significant when compared with historical control data. Male fish exposed to $\mathrm{EE}_{2}$ at $4.0 \mathrm{ng} / \mathrm{L}$ failed to develop normal secondary sexual characteristics; on the other hand, assumed females exposed to this level of $\mathrm{EE}_{2}$ were able to breed when paired with males that had not been exposed to $\mathrm{EE}_{2}$. Histology of $\mathrm{F}_{0}$ control, $0.2-$, and $1-\mathrm{ng} / \mathrm{L}$ exposed fish at $56 \mathrm{~d}$ posthatch indicated an approximate female-to-male ( $\mathrm{F}: \mathrm{M}$ ) sex ratio of 50:50 (with no ovatestes observed in the control), while fish exposed to $\mathrm{EE}_{2}$ at $4.0 \mathrm{ng} / \mathrm{L}$ for $56 \mathrm{~d}$ posthatch had a $\mathrm{F}$ : $\mathrm{M}$ sex ratio of 84:5 (with ovatestes in $11 \%$ of fish). After $172 \mathrm{~d}$ posthatch, no testicular tissue was observed in any fish exposed to $\mathrm{EE}_{2}$ at $4.0 \mathrm{ng} / \mathrm{L}$. At the same time point, plasma vitellogenin levels were significantly higher in fish exposed to $\mathrm{EE}_{2}$ at $16 \mathrm{ng} /$ $\mathrm{L}$. A lack of sexual differentiation occurred in males at concentrations $\geq 4.0 \mathrm{ng} / \mathrm{L}$. Taking into account these data, the overall nom observed-adverse-effect concentration was considered to be $1.0 \mathrm{ng} / \mathrm{L}$.
\end{abstract}

Keywords-Ethinylestradiol Endocrine disruptor Estrogen Life-cycle Fish

\section{INTRODUCTION}

The potential impact of natural and synthetic estrogens on aquatic ecosystems has become a subject of vast interest in recent years. Field reports of reproductive problems in some European freshwater fish populations have led to concern over the possible role of environmental estrogens as relevant factors $[1,2]$. The publication of these and related findings has led to an intensive international effort to understand the wider significance of xenestrogens and other classes of endocrine disruptors for ecological risk assessment [3-5]. Fieldwork was followed by laboratory studies to try to identify the potential causes, focusing attention on natural steroids and alkylphenols [6-9]. Synthetic estrogens, which are widely used in contraception and related pharmaceutical purposes, have also been shown to enter the aquatic environment via effluent discharges from sewage treatment works [10-14]. The synthetic steroid 17- $\alpha$-ethinylestradiol $\left(\mathrm{EE}_{2}\right)$ has become one of the most commonly used active ingredients for oral contraception $[15,16]$. In the past decade, $\mathrm{EE}_{2}$ has occasionally been detected in sewage treatment work effluents at the low $\mathrm{ng} / \mathrm{L}$ range and has very occasionally been detected in surface waters in the United Kingdom [10], Germany [13,14], and Israel [17]. Alerted by reports of intersex fish in the settlement lagoons of sewage treatment works during the 1980s, Purdom et al. [1] showed that $\mathrm{EE}_{2}$ concentrations of $10 \mathrm{ng} / \mathrm{L}$ in water could induce the synthesis of vitellogenin in immature cyprinids and

* To whom correspondence may be addressed (reinhard.laenge@schering.de). at levels as low as $0.1 \mathrm{ng} / \mathrm{L}$ in rainbow trout. Vitellogenin synthesis is an estrogen receptor-mediated response, occurring naturally in female fish following endogenous estrogen exposure via blood plasma [18]. Vitellogenin induction in juvenile or adult male fish can therefore be used as a biomarker of exposure to exogenous steroidal estrogens [19]. The health implications of vitellogenin induction in juvenile or adult male fish is an important question that presently remains to be studied. Consideration should be given to the developmental and reproductive patterns in fish populations, for example, through fish full life-cycle studies that include the measurement of vitellogenin, developmental, and reproductive parameters. It is known that exposure to steroid hormones influences sexual differentiation, with estrogens and androgens being used in aquaculture for the induction of sex reversal in commercial species [20].

In order to investigate the ecotoxicological effects of $\mathrm{EE}_{2}$ and to define the relationship between vitellogenin measurements, gonad histology, and gross developmental and reproductive effects, a fish full life-cycle (FFLC) study was conducted using the fathead minnow. The protocol was basect primarily on the U.S. Environmental Protection Agency's (U.S. EPA's) FFLC Standard Evaluation Procedure (including evaluation of survival, growth, development, and reproduction over two generations) [21] and supplemented with histology (liver, kidney, and gonad) and vitellogenin analyses. The key aims of the study were, first, to define the $\mathrm{EE}_{2}$ dose response and the no-observed-adverse effect concentration for $\mathrm{EE}_{2}$ over a multigenerational exposure and, second, to address whether 
biomarkers of endocrine disruption, such as changes in vitellogenin and gonad histology, were indicative of impairment of reproduction and development.

\section{MATERIALS AND METHODS}

\section{Test substance}

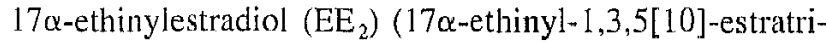
ene-3,17\%-diol) with a purity of $100 \%$ and ${ }^{1+4} \mathrm{C}$-(ethinyl)-radiolabeled $\mathrm{EE}_{2}$ with a purity of $99.5 \%$ and a specific activity of $5.54 \mathrm{MBq} / \mathrm{mg}$ were used (both supplied by Schering, Berlin, Germany). Test solutions were prepared by direct addition of $\mathrm{EE}_{2}$ into the dilution water to make a defined stock solution at each test concentration $(0.2,1.0,4.0,16$, and $64 \mathrm{ng} / \mathrm{L})$. No carrier solvents were employed in this study (water solubility of $\mathrm{EE}_{2} \sim 20 \mathrm{mg} / \mathrm{L}$ at $25^{\circ} \mathrm{C}$; Schering, unpublished data).

\section{Test species}

The freshwater fathead minnow, Pimephales promelas (Teleostei: Cyprinidae), was selected as the test fish, given its suitability for life-cycle toxicity testing as demonstrated over several decades [22]. Fish, originally supplied by Osage Catfisheries (Osage Beach, MO, USA) were cultured at the Brixham Environmental Laboratory (Devon, United Kingdom). Brood stock were fed daily on a mixed diet of Promin fish pellets (Trouw UK, Preston, UK) and defrosted adult brine shrimp and were maintained under a 16:8-h light:dark photoperiod to allow natural spawning onto polyethylene tiles. To start the FFLC test with $\mathrm{EE}_{2}$, embryos $<24$ h postfertilization ( $<1 \mathrm{~d}$ postfertilization) were collected from at least three spawnings from the Brixham culture facility, as required by the standard protocol [19]. Batches of embryos from $11 \mathrm{fe}-$ males were microscopically examined, pooled, and randomly allocated in groups of five embryos to each exposure group incubation cup. The process was repeated until each incubation cup contained 25 embryos, with four cups per treatment. The study began on July 11, 1995, and continued over 301 days until May 5, 1996.

\section{Test method and exposure conditions}

Test apparatus. A continuous flow-through system was employed, using test vessels constructed of glass with a minimum of other materials (silicon rubber tubing and adhesive). The progeny exposure tanks (four per treatment) were rectangular aquaria with a working volume of $9.5 \mathrm{~L}$, while the adult exposure tanks (two per treatment, each optionally divided into four compartments) had a working volume of $45 \mathrm{~L}$. Embryo incubation cups (glass cylinders with a base of $0.4-\mu \mathrm{m}$ nylon mesh) were suspended in the progeny tanks, each cup holding 25 embryos, and oscillated vertically twice per minute in the test solution.

The dilution water was fed from a temperature controlled aerated header tank via flow control devices to glass mixing chambers (flow rate $700 \mathrm{ml} / \mathrm{min}$ ). The test substance stock solution was fed by peristaltic pump controlled at a constant rate of $0.05 \mathrm{ml} / \mathrm{min}$. The mixing chambers were fitted with independent magnetic stirrers to ensure adequate mixing of the test solutions. The test solutions passed from the mixing chambers into flow-splitting chambers, supplying at least six tank volumes per day to the progeny or adult tanks. The flows to the progeny or adult tanks were controlled at 50 or $225 \mathrm{ml} /$ min. The flow system was checked daily for correct operation and measurements of flow rates.

When $F_{0}$ adult fish were expected to begin spawning, the adult exposure tanks were separated into four breeding chambers by inserting three vertical screens made of perforated stainless steel into the tanks. This provided ample space for the pairs to breed, good mixing of the test solution throughout the tank, and ease of access for fish observation.

Dilution water. The dilution water was from the municipal supply to Brixham, Devon, United Kingdom and was filtered through activated carbon and dechlorinated with sodium thiosulfate. Treated water was passed through an ultraviolet sterilizer and another series of Hytrex cartridge filters (25- and $10-\mu \mathrm{m}$ rating) (Osmonics, Minnetonka, MN, USA). This filtered water was then fed into the header tank and, prior to delivery to the exposure system, finally filtered to $5.0 \mu \mathrm{m}$. Where necessary, water hardness was increased by addition of mineral salts (including $\mathrm{CaCl}_{2}, \mathrm{MgSO}_{4}, \mathrm{KCl}$, and $\mathrm{NaHCO}_{3}$ ) to maintain hardness $\geq 40 \mathrm{mg} / \mathrm{L}$ as $\mathrm{CaCO}_{3}$ [21].

Range-finding studies. The selection of the $\mathrm{EF}_{2}$ test concentrations for the definitive FFLC study was based on results from 28-d prelininary studies. Initially, 24-h-old embryos were exposed to $\mathrm{EE}_{2}$ at $0,10,100,1,000$, and $10,000 \mathrm{ng} / \mathrm{L}$ (nominal values), incubated through hatching ( $4-5$ d at $25 \pm$ $1^{\circ} \mathrm{C}$ ) and larval development. After $32 \mathrm{~d}$ posthatch, it was found that weight and length were equally sensitive endpoints, both being significantly reduced at $\mathrm{EE}_{2}$ concentrations of $\geq 100$ ng/L (data noc shown, $p<0.05$ ). Adult fish were also exposed to the same concentrations in order to study the effects of $\mathrm{EE}_{2}$ on fecundity. The most prominent finding in the adult fish range-finding study was the total lack of spawning at any $\mathrm{EE}_{2}$ concentration, giving a 28 -d no-observed-effect concentration (NOEC) of $<10 \mathrm{ng} / \mathrm{L}$. On the basis of these data, the definitive FFLC study was set up using nominal $\mathrm{EE}_{2}$ concentrations of $0.2,1.0,4.0,16$, and $64 \mathrm{ng} / \mathrm{L}$, together with a dilution water control.

Definitive study-Preparation of test solutions. A stock solution of $10 \mathrm{mg} / \mathrm{L}$ (nominal) was prepared by dissolving $\mathrm{EE}_{2}$ in deionized water; followed by stirring and warming to $35^{\circ} \mathrm{C}$. After cooling to $25^{\circ} \mathrm{C}$, the stock solution was continually stirred, reheated to $35^{\circ} \mathrm{C}$, and ultrasonicated for $5 \mathrm{~min}$ and then allowed to cool. This stock solution was divided into aliquots and stored at $-20^{\circ} \mathrm{C}$ until required. Storage stability under these conditions was confirmed during earlier experiments.

In this study, ${ }^{14} \mathrm{C}-\mathrm{EE}_{2}$ was used to facilitate analytical monitoring of the nominal test concentrations. For this purpose, a ${ }^{14} \mathrm{C}_{-E_{2}}$ stock solution $(40 \mathrm{MBq}$ and $7.22 \mathrm{mg} / \mathrm{L}$ ) was prepared by first dissolving ${ }^{14} \mathrm{C}-\mathrm{EE}_{2}$ in $100 \%$ methanol, evaporating to dryness, and then dissolving in deionized water under stirring at $35^{\circ} \mathrm{C}$. The ${ }^{14} \mathrm{C}-\mathrm{EE}_{2}$ stock solution was divided in aliquots and stored at $-20^{\circ} \mathrm{C}$. One day prior to use, the thawed aliquot concentration was checked by liquid scintillation counting. Calculated volumes of the ${ }^{14} \mathrm{C}-\mathrm{EE}_{2}$ stock solution were then diluted with dechlorinated water before use.

Exposure procedure. The exposure system was run for 12 d prior to introduction of test organisms in order to saturate all surfaces with the test substance and to monitor the function of the system. For each exposure concentration, including the control, replicate systems (two adult tanks and four progeny tanks) were established. $F_{0}$ embryo exposure commenced by placing two incubation cups, each containing 25 embryos, into each progeny tank (giving 200 embryos per test concentration).

After completion of $\mathrm{F}_{0}$ hatching ( $4 \mathrm{~d}$ postfertilization $=0$ $\mathrm{d}$ posthatch), 25 larvae were randomly selected from the nominal 50 larvae pooled from the two embryo incubation cups and released into the progeny lank (giving 100 larvae per test. 
concentration). At 56 d posthatch, 50 subadult fish were randomly selected from the progeny tanks and divided equally into the adult tanks, giving 50 fish per group (controls and 0.2-64 $\mathrm{ng} / \mathrm{L}$ test concentrations). The remaining fish were sacrificed in buffered MS222 (500 $\mathrm{mg} / \mathrm{L}$ ) and fixed in formalin for histology [23].

At $158 \mathrm{~d}$ posthatch (162 d postfertilization), all fish from the 64-ng/L exposure group were sacrificed because of their stunted development (see Results section for full details). Randomly selected whole fish subsamples were either snap frozen on dry ice and stored at $-20^{\circ} \mathrm{C}$ until required for vitellogenin quantification or fixed for histology. At $172 \mathrm{~d}$ posthatch, sexual differentiated fathead minnows were observed in the control, 0.2-, and 1.0-ng/L treatments. Stainless-steel dividers were placed into these adult tanks to divide each tank into four equal sized breeding chambers (chamber working volume $\sim 11$ L). One male and one female were randomly paired and placed into each chamber (giving eight breeding pairs per test concentration), and one spawning tile was provided for each pair. Since the $F_{0}$ fish in the remaining test concentrations ( 4.0 and $16 \mathrm{ng} / \mathrm{L}$ ) had not overtly sexually differentiated by $172 \mathrm{~d}$ posthatch, several spawning tiles were placed into each adult tank to initiate mixed pairing and spawning. Each spawning tile was checked daily for eggs and embryos, which were removed and counted, and embryological development was examined microscopically. For each replicate adult tank (control, 0.2, and $1.0 \mathrm{ng} / \mathrm{L}$ only), embryo hatchability and $F_{1}$ early life-stage studies were subsequently conducted as per the method used for the $F_{0}$ generation. The $F_{1}$ early life-stage studies were continued with two $\mathrm{EE}_{2}$ exposure groups of 0.2 and $1.0 \mathrm{ng} / \mathrm{L}$ and a control up to 28 d posthatch (32 d postfertilization). After sacrificing in bulfered MS222, fish were weighed, measured, and fixed for histology.

At $245 \mathrm{~d}$ posthatch, the adult fish from the $16 \mathrm{mng} / \mathrm{L}$ exposure group were sacrificed. These fish were randomly subsampled for either vitellogenin quantification, analysis of ${ }^{14} \mathrm{C}-\mathrm{EE}_{2}$ bioconcentration, or histology. At $285 \mathrm{~d}$ posthatch, eight $\mathrm{F}_{0}$ fish (suspected females) from the $4.0 \mathrm{ng} / \mathrm{L}$ exposure group were transferred to clean dilution water to investigate any possible recovery from the effect of $\mathrm{EE}_{2}$ exposure. After approximately $14 \mathrm{~d}$, these presumed females were parred with unexposed males (from the same cohort as the $F_{0}$ test animals) and the pairs monitored for spawning. The termination of the $F_{0}$ study was at $301 \mathrm{~d}$ posthatch, when all remaining adult fish were sacrificed and fixed for histology. These steps are summarized in the Appendix.

Test conditions. The water quality in the test solutions (as conductivity, hardness, oxygen, temperature, and $\mathrm{pH}$ ) was measured twice per week, Laboratory light intensity was measured on four occasions during the study; results ranged from 490 to 680 Lux. For the first five months of the study, the photoperiod was controlled so that day length gradually increased from $10 \mathrm{~h} 45 \mathrm{~min}$ at $0 \mathrm{~d}$ posthatch to $14 \mathrm{~h} 15 \mathrm{~min}$ at $139 \mathrm{~d}$ posthatch. For the next four months (spawning period), day length was further increased to 15 h 45 min $(155-261 \mathrm{~d}$ posthatch) and thereafter gradually reduced to $13 \mathrm{~h} 30 \mathrm{~min}$ for the postspawning period. This changing photoperiod regime reflected the natural environment of the fathead minnow and ensured spawning began after $150 \mathrm{~d}$ posthatch and follows the U.S. EPA guidance [21].

\section{Analysis of $\mathrm{EE}_{2}$ concentrations-Radioimmunoassay}

The concentration of nonradiolabeled $\mathrm{EE}_{2}$ was measured by radioimmunoassay (RIA) at Schering, Berlin, Germany.
Samples of $500 \mathrm{ml}$ were taken once weekly from each test concentration and control, and 30 to $140 \mathrm{ml}$ (depending on concentration) were extracted by solid-phase extraction using methanol primed Sep-Pak Plus C18 SPE cartridges (Isolute $500 \mathrm{mg}, \mathrm{C} 18 / 6 \mathrm{ml}$ ) (Waters, Milford, MA, USA). The columns were washed with HPLC (ultrapurified) grade water to elute undesired compounds and then subsequently dried at approximately $20^{\circ} \mathrm{C}$. The $\mathrm{EE}_{2}$ on the columns was then eluted with $1.0 \mathrm{ml}$ of $100 \%$ methanol and the eluate air dried, and residues were then redissolved in $0.8 \mathrm{ml}$ bovine serum albumen buffer. Rabbit antisera raised against bovine serum albumen conjugated $\mathrm{EE}_{2}$ was employed for the RIA, which also used ${ }^{3} \mathrm{H}$ labeled $\mathrm{EE}_{2}$ with a specific activity of $1.5 \mathrm{TBq} / \mathrm{mM}$ as a tracer. For RIA analyses, $0.8 \mathrm{ml}$ of the redissolved residues were mixed with $0.1 \mathrm{ml}$ of antiserum suspension (dilution 1: 300,000 ) and $0.1 \mathrm{ml}$ tracer solution. After $16 \mathrm{~h}$ incubation at $4^{\circ} \mathrm{C}, 0.2 \mathrm{ml}$ of dextran-coated charcoal suspension were added and vortexed. After 15 min incubation, the aqueous phase was separated by centrifugation $\left(10,000 \mathrm{~g}, 20^{\circ} \mathrm{C}, 20 \mathrm{~min}\right)$ and analyzed by radiochemistry after addition of $4.5 \mathrm{ml}$ of scintillation cocktail.

\section{Analysis of ${ }^{14} C-E E_{2}$ concentrations in water and fish}

The test concentration of ${ }^{14} \mathrm{C}-\mathrm{EE}_{2}$ was analyzed by means of liquid scintillation counting. Samples $(2.0 \mathrm{~L})$ were taken weekly, and $20 \mathrm{ml}$ methanol per sample were added and then passed through a Sep-Pak Plus C18 SPE cartridges (Isolute $500 \mathrm{mg}, \mathrm{C} 18 / 6 \mathrm{ml}$ ). Cartridges were extracted with $100 \%$ methanol before analysis by liquid scintillation. For measurement of potential bioconcentration of ${ }^{14} \mathrm{C}_{-} \mathrm{EE}_{2}$ in whole body tissues stored at $-20^{\circ} \mathrm{C}$, three fish per treatment were combusted, and the collected ${ }^{14} \mathrm{CO}_{2}$ was analyzed by liquid scintillation counting. The bioconcentration factor $(\mathrm{BCF})$ was calculated by dividing the mean tissue level of $\mathrm{EE}_{2}$ by the liquid scintillation counting measured mean test concentration.

\section{Vitellogenin analysis}

For vitellogenin analysis, equal numbers of male and female fish were sampled from the exposure and control groups, where visual differentiation of gender was possible, and sacrificed in buffered MS222 (500 mg/L). Blood samples were obtained by cardiac puncture, using a heparinized syringe $(5,000$ units $/ \mathrm{ml})$. The blood samples were centrifuged $\left(10,000 \mathrm{~g}, 20^{\circ} \mathrm{C}, 5 \mathrm{~min}\right)$ and the plasma vitellogenin levels quantified using a homologous catp (Cyprinus carpio) vitellogenin RIA [24]. Fish too small for blood sampling (at 16 and $64 \mathrm{ng} / \mathrm{L}$ ) were thawed and homogenized prior to vitellogenin analysis, as per Tyler and Lancaster [25]. After centrifugation $\left(10,000 \mathrm{~g}, 20^{\circ} \mathrm{C}, 5\right.$ min), the vitellogenin RIA was applied to whole body homogenates in the manner described for the fathead minnow plasma samples. The vitellogenin data were normalized for fish wet weight (ng vitellogenin $/ \mathrm{ml} / \mathrm{g}$ fish), thereby allowing comparison of vitellogenin levels in whole body homogenates and plasma samples.

\section{Histological analysis}

Gonads and kidneys of treated and untreated fish were analyzed for abnormalities. For this purpose, formalin-fixed fish were dehydrated and processed for paraflin wax embedding. Segments of the whole abdominal body region were obtained by transverse sections cut at the cranial ridge of the dorsal fin at a thickness of 5 to $10 \mathrm{~mm}$. These body segments were used to obtain 4- to $6-\mu \mathrm{m}$ sections that were then stained with 
Table 1. Radioimmunoassay (RIA) and liquid scintillation counting (LSC) data for the ethinylestradiol (EE ( $_{2}$ exposure concentrations

\begin{tabular}{|c|c|c|c|c|c|c|c|}
\hline \multirow{2}{*}{$\begin{array}{l}\text { Type of } \\
\text { analysis }\end{array}$} & \multirow[b]{2}{*}{ Parameter } & \multicolumn{6}{|c|}{ Nominal concentration of $\mathrm{EE}_{2}(\mathrm{ng} / \mathrm{L})$} \\
\hline & & Control & 0.2 & 1.0 & 4.0 & 16 & 64 \\
\hline \multirow[t]{4}{*}{ RIA } & Mean & 0.45 & 0.59 & 1.03 & 3.20 & 13.1 & 54.0 \\
\hline & SD & 0.43 & 0.44 & 0.19 & 0.46 & 1.55 & 6.27 \\
\hline & $n$ & 17 & 17 & 17 & 17 & 17 & 17 \\
\hline & $\%$ Nominal & - & 295 & 103 & 80 & 82 & 84 \\
\hline \multirow{2}{*}{ Blank corrected" } & Mean & - & 0.14 & 0.58 & 2.75 & 12.67 & 53.55 \\
\hline & $\%$ Nominal & - & 70 & 58 & 69 & 79 & 84 \\
\hline \multirow[t]{4}{*}{ LSC } & Mean & - & 0.16 & 0.76 & 2.80 & 12.1 & 46.8 \\
\hline & $\mathrm{SD}$ & - & 0.03 & 0.16 & 1.05 & 2.41 & 11.0 \\
\hline & $n$ & & 18 & 18 & 14 & 14 & 8 \\
\hline & $\%$ Nominal & - & 80 & 76 & 70 & 75 & 73 \\
\hline
\end{tabular}

"For concentrations measured in control (likely due to nonspecific binding in RIA).

hematoxylin and eosin for histological examination. The sectioning of the paraffin blocks was monitored microscopically in steps of $200 \mu \mathrm{m}$ until the gonads became visible on both sides.

\section{In-life phase biological observations}

Numbers of live and dead embryos were recorded daily, and after hatching, numbers of live, deformed, and dead larvae were also monitored. The percentage hatch was calculated as the number of hatched fish larvae in each progeny tank versus the number of embryos added initially. During the $F_{0}$ juvenile phase, mortality, behavior, and appearance were observed, and any abnormal effect was recorded. At $F_{0} 28 \mathrm{~d}$ posthatch and $56 \mathrm{~d}$ posthatch, all surviving fish were photographed, and standard length (snout to base of tail) was determined. At $56 \mathrm{~d}$ posthatch, bulk wet weight (weight of the whole group of fish, not individual weight) was also determined. When $F_{0}$ adult fish had been paired ( $172 \mathrm{~d}$ posthatch), all eggs were collected, counted, and observed under the microscope. For the $F_{1}$ early life-stage tests, when the embryos hatched, the percentage hatch and survival of the $F_{1}$ fish were recorded in the same way described for the $F_{01}$ generation. At the end of the $F_{1}$ early life-stage tests ( $28 \mathrm{~d}$ posthatch), fish wet weight and standard length were determined.

\section{Statistical analyses}

Treatment groups were compared with the control group in all cases, with replicate data being pooled for comparison, unless otherwise detailed. All significant differences are reported at the $5 \%$ significance level. The $\mathrm{F}_{0}$ percentage hatch data were tested using the Steel's many-one rank test [26] to compare the treatments with the control. The $F_{1}$ percentage hatch clata were analyzed by pooling the number of eggs laid and hatched for each breeding pair of fish and then using the nonparametric Wilcoxon rank-sum test [27] to compare the percentage hatch figures. The percentage survival data were tested using an exact 2 by 2 contingency table test to compare the treatments with the control. The contingency table tests show the percentage significance between replicates and between treatments. This is a two-sided test, and with the $5 \%$ level being considered a significant difference, any number less than 5 in the tabular output indicates a significant difference. The $F_{0}$ and $F_{1}$ length and weight clata from each replicate of each treatment were tested using Wilcoxon's rank-sum test. Egg production data were tabulated to give the number of batches of eggs, number of eggs per batch, total eggs, mean eggs per batch, and the range of egg numbers for each treat- ment. From the onset of egg production (exposure day 178) to the end of the study, the egg production in each of four separate breeding chambers has been recorded separately. The number of eggs produced per available female-day have been calculated, and these data were analyzed using Wilcoxon's rank-sum test. From these analyses, the NOEC and LOEC were identified for the various life stages.

\section{RESULTS}

\section{Water quality and dietary analyses}

All water quality parameters were within recommended guidelines for chronic tests with fathead minnows [21]. Also, analyses of all diets used for the fish life-cycle study identified only trace levels of heavy metals (data not shown). Brine shrimp cysts contained $\Sigma$ organochlorine pesticides of 364 to $366 \mu \mathrm{g} / \mathrm{kg}$ and $\Sigma$ polychlorinated biphenyls $(\mathrm{PCBs})<0.005$ $\mu \mathrm{g} / \mathrm{kg}$, while frozen brine shrimp contained $\Sigma$ organochlorine pesticides $<0.005 \mu \mathrm{g} / \mathrm{kg}$ and $\Sigma$ PCBs $<0.005 \mu \mathrm{g} / \mathrm{kg}$. Promin contained $\Sigma$ organochlorine pesticides $<0.01$ to $6 \mu \mathrm{g} / \mathrm{kg}$ and $\Sigma$ PCBs $<0.01 \mu \mathrm{g} / \mathrm{kg}$ (all analysis by Trouw Nutrition, Whitham, Essex, UK).

\section{$E E_{2}$ exposure concentrations}

The RIA and liquid scintillation counting data for the $\mathrm{EE}_{2}$ exposure levels are given in Table 1. The RIA method appeared to overestimate the actual concentrations, this being most evident in the $0.2-$ and $1.0-\mathrm{ng} / \mathrm{L}$ treatments. It is unlikely that the control contained any $\mathrm{EE}_{2}$; hence, the value of $0.45 \mathrm{ng} / \mathrm{L}$ probably atose from nonspecific binding of the antiserum to natural steroids normally excreted by fish. Based on both the RIA and the ${ }^{14} \mathrm{C}_{-} \mathrm{EE}_{2}$ analyses, the actual concentrations of $\mathrm{EE}_{2}$ ranged from 58 to $84 \%$ of nominal values, which are considered acceptable for such long-term studies and at such low nominal concentrations. All biological results reported were therefore based on nominal concentrations.

\section{$E E_{2}$ bioconcentration data}

The concentration of $\mathrm{EE}_{2}$ in fish tissues after $158 \mathrm{~d}$ posthatch $(64 \mathrm{ng} / \mathrm{L})$ and $245 \mathrm{~d}$ posthatch $(16 \mathrm{ng} / \mathrm{L})$ produced $\mathrm{BCF}$ values of 660 and 610 , respectively (Table 2). The $0.2-$ and $1.0 \mathrm{ng} / \mathrm{L}$ test concentrations gave no detectable tissue concentrations $(<0.38 \mathrm{ng} / \mathrm{g}$ ) after $192 \mathrm{~d}$ posthatch; therefore, a BCF could not be calculated. Since the 16- and 64-ng/L concentrations induced toxic effects in $\mathrm{F}_{0}$ ish, and considering that BCFs should not be derived from moribund animals, the BCF for $\mathrm{EE}_{2}$ in healthy fish is likely to be $<500$ but certainly below 
Table 2. Whole body residue analyses including bioconcentration factor $(B C F)$ in $F_{0}$ fathead minnows exposed to ${ }^{14} \mathrm{C} \cdot \mathrm{EE}_{2}{ }^{3}$

\begin{tabular}{ccccc}
\hline & $\begin{array}{c}\text { Nominal } \mathrm{EE}_{2} \\
\text { concen- } \\
\text { tration } \\
\text { (ng/L) }\end{array}$ & $\begin{array}{c}\text { Mean } \mathrm{EE}_{2} \text { concentration } \\
\text { DPHesured } \\
\left(\mathrm{ng} / \mathrm{L}^{-1}\right)\end{array}$ & $\begin{array}{c}\text { In fish } \\
\left(\mathrm{ng} / \mathrm{g}^{-1}\right)\end{array}$ & BCF \\
\hline 153 & 64 & 47 & 31 & 660 \\
239 & 16 & 12 & 7.3 & 610 \\
192 & 1.0 & 0.76 & $<0.38$ & $<500$ \\
192 & 0.2 & 0.16 & $<0.38$ & $<2400$ \\
\hline
\end{tabular}

"Tissue ${ }^{14} \mathrm{C}$-EE2 activity measured in whole body homogenates.

b $\mathrm{DPH}=$ days posthatch.

2,400. A more exact determination was impossible because of analytical limitations.

\section{In-life phase biological observations}

Hatchability of $F_{0}$ embryos. The hatching success of the control embryos was $93.3 \pm 5.03 \%$ (mean \pm standard deviation [SD]) and ranged from 88.8 to $92.5 \%$ in the $\mathrm{EE}_{2}$ exposure groups. There was no evidence of a dose response in hatching success versus $\mathrm{EE}_{2}$ exposure, and statistical analysis indicated that none of the exposure concentrations were significantly different from controls (Table 3).

Survival of $F_{0}$ larvae and juvenile fish. At $28 \mathrm{~d}$ posthatch, survival was $\geq 80 \%$, except in the higher $\mathrm{EE}_{2}$ concentrations of 16 and $64 \mathrm{ng} / \mathrm{L}$ (78 and $75 \%$, respectively). Survival between $28 \mathrm{~d}$ posthatch and $56 \mathrm{~d}$ posthatch was $\geq 77 \%$ in the control and all EE $E_{2}$ exposure groups, except at the highest concentration of $64 \mathrm{ng} / \mathrm{L}$ (69\% survival at $56 \mathrm{~d}$ posthatch). All differences were not statistically significant.

Growth of $F_{0}$ larvae and juveniles. The data for growth are summarized in Table 3. Statistical analysis of the standard lengtli data at $28 \mathrm{~d}(n=75-91)$ and $56 \mathrm{~d}(n=69-89)$ posthatch indicated a significant reduction in Iength at $\geq 16 \mathrm{ng} / \mathrm{L}$ by 28 $d$ posthatch $(p<0.05)$ and also at $\geq 4.0 \mathrm{ng} / \mathrm{L}$ by $56 \mathrm{~d}$ posthatch $(p<0.05)$. Mean bulk wet weight, measured at $56 \mathrm{~d}$ posthatch, was significantly reduced at 4,16 , and $64 \mathrm{ng} / \mathrm{L}$. Overall, standard length was a more sensitive index of $E_{2}$-induced growth inhibition than bulk wet weight, presumably since lengths were taken on an individual basis compared with bulk weighing. In summary, therefore, the overall NOEC and LOEC values for juvenile fish growth exposed to $\mathrm{EE}_{2}$ until $56 \mathrm{~d}$ posthatch were 1.0 and $4.0 \mathrm{ng} / \mathrm{L}$, respectively.

Gross morphological changes in $F_{a}$ fish. Fish from the 16 and 64-ng/L exposure groups exhibited severe physical deformities. The most prominent finding was anal protrusion, with distended abdomens (which resulted in some cases in an upward curvature of the spine) in all fish exposed at $64 \mathrm{ng} / \mathrm{L}$ and in approximately 40 to $50 \%$ of fish exposed to $16 \mathrm{ng} / \mathrm{L}$ for several weeks. Many fish exposed to $64 \mathrm{ng} / \mathrm{L}$ also showed hemorrhaging. Fish from exposure groups $\geq 4.0 \mathrm{ng} / \mathrm{L}$ began to show sexual differentiation after $172 \mathrm{~d}$ posthatch, in that immature or female individuals were observed; however, no males (with appropriate secondary sexual characteristics and territorial behavior) were seen at this time. Consequently, the initiation of breeding pairs and the spawning phase of the study could only be conducted with the control, $0.2-$, and $1.0-\mathrm{ng} / \mathrm{L}$ exposure groups.

Survival and growth of $F_{0}$ adults. Survival of adult fish during pairing and egg laying (176-301 d posthatch) was analyzed for the control, 0.2-, and 1.0-ng/L exposure groups (Table 4). There were no significant differences between sulvival in the exposure group fish versus controls; however, mean percentage survival was $62.5 \%$ at $1.0 \mathrm{ng} / \mathrm{L}$ compared with $87.5 \%$ in the control group $(n=8)$. Although mortality in the $1.0-\mathrm{ng} / \mathrm{L}$ exposure group was primarily in male fish, it was unlikely that this is was a toxic effect due to $\mathrm{EE}_{2}$ since more sensitive parameters (length and wet weight) did not indicate any $\mathrm{EE}_{2}$-induced adverse effects in male fish. The standard length and wet-weight data were analyzed for the controls, $0.2-$, and $1.0-\mathrm{ng} / \mathrm{L}$ concentration at $301 \mathrm{~d}$ posthatch (separately for males vs females since adult male fathead minnows are

Table 3. Effect of ethinylestradiol $\left(\mathrm{EE}_{2}\right)$ exposure on hatching success, survival, and growth of $\mathrm{F}_{0}$ fathead minnows up to $56 \mathrm{~d}$ posthatch ${ }^{n}$

\begin{tabular}{|c|c|c|c|c|c|}
\hline \multirow{2}{*}{$\begin{array}{l}\text { Test } \\
\text { concentration } \\
\text { (ng/L) }\end{array}$} & \multirow{2}{*}{$\begin{array}{l}\text { Exposure } \\
\text { duration } \\
\text { (DPH }\end{array}$} & \multicolumn{4}{|c|}{ Effect endpoint } \\
\hline & & $\begin{array}{c}\% \text { Hatching } \\
(n=200 \pm 3)\end{array}$ & $\begin{array}{l}\% \text { Survival } \\
(n=100)\end{array}$ & $\begin{array}{c}\text { Standard } \\
\text { Iength }(\mathrm{mm})\end{array}$ & $\begin{array}{l}\text { Bulk wet } \\
\text { weight (mg) }\end{array}$ \\
\hline \multirow[t]{3}{*}{ Control } & 1 & $93.3 \pm 5.73$ & - & - & - \\
\hline & 28 & - & $87.0 \pm 5.03$ & $19.4 \pm 1.92$ & - \\
\hline & 56 & - & $85.0 \pm 5.03$ & $29.8 \pm 3.34$ & $563 \pm 28.7$ \\
\hline \multirow[t]{3}{*}{0.2} & l & $88.8 \pm 4.99$ & - & - & - \\
\hline & 28 & - & $91.0 \pm 3.83$ & $19.4 \pm 1.50$ & - \\
\hline & 56 & - & $89.0 \pm 6.00$ & $29.9 \pm 3.24$ & $555 \pm 17.3$ \\
\hline \multirow[t]{3}{*}{1.0} & 1 & $92.5 \pm 4.73$ & - & - & - \\
\hline & 28 & - & $80.0 \pm 10.3$ & $19.4 \pm 1.71$ & - \\
\hline & 56 & - & $80.0 \pm 10.3$ & $29.7 \pm 2.77$ & $543 \pm 5.00$ \\
\hline \multirow[t]{3}{*}{4.0} & 1 & $90.5 \pm 8.39$ & - & - & - \\
\hline & 28 & - & $91.0 \pm 2.00$ & $19.2 \pm 1.62$ & - \\
\hline & 56 & - & $88.0 \pm 4.62$ & $28.5 \pm 2.28 *$ & $488 \pm 20.6^{*}$ \\
\hline \multirow[t]{3}{*}{16} & 1 & $89.0 \pm 6.00$ & - & - & - \\
\hline & 28 & - & $78.0 \pm 6.93$ & $18.2 \pm 1.51^{*}$ & - \\
\hline & 56 & - & $77.0 \pm 5.03$ & $26.7 \pm 2.27$ 佻 & $433 \pm 26.3^{*}$ \\
\hline \multirow[t]{3}{*}{64} & 1 & $89.5 \pm 5.45$ & - & - & - \\
\hline & 28 & - & $75.0 \pm 8.87$ & $16.2 \pm 1.64 *$ & - \\
\hline & 56 & 一 & $69.0 \pm 6.83$ & $22.2 \pm 2.14^{*}$ & $280 \pm 18.3^{*}$ \\
\hline
\end{tabular}

"Values as mean \pm standard deviation. Standard length data at 28 and $56 \mathrm{~d}$ posthatch recorded photographically. Wet weight not determined at 1 and $28 \mathrm{~d}$.

"DPH = days posthatch.

$*=$ significantly less than controls $(p<0.05)$. 
Table 4. Effect of ethinylestradiol $\left(\mathrm{EE}_{2}\right)$ exposure on survival and growth of $\mathrm{F}_{0}$ fish up to $301 \mathrm{~d}$ posthatch

\begin{tabular}{llccc}
\hline & & & Nominal $E_{2}$ concentration $(\mathrm{ng} / \mathrm{l})$ \\
\cline { 2 - 4 } Fish & $\begin{array}{c}\text { Endpoint }(n=5-8, \\
\text { males and females together) }\end{array}$ & Control & 0.2 & 1.0 \\
\hline$F_{0}$ & Survival & $87.5 \pm 17.7$ & $100 \pm 0$ & $62.5 \pm 0$ \\
& Female standard length $(\mathrm{mm})$ & $55.4 \pm 2.63$ & $54.1 \pm 4.64$ & $53.0 \pm 2.27$ \\
& Male standard length $(\mathrm{mm})$ & $71.0 \pm 5.74$ & $73.0 \pm 2.06$ & $73.7 \pm 2.45$ \\
& Female wet weight $(\mathrm{g})$ & $3.30 \pm 0.72$ & $2.90 \pm 0.77$ & $2.68 \pm 0.44 *$ \\
& Male wet weight $(\mathrm{g})$ & $7.41 \pm 1.35$ & $9.19 \pm 1.37$ & $8.52 \pm 1.11$ \\
\hline
\end{tabular}

a Values as mean it standard deviation.

* = significantly less than control group $(p<0.05)$.

naturally markedly larger than females). For males, no significant differences were detected (Table 4). For females, there was a $19 \%$ reduction in wet weight in the $1.0-\mathrm{ng} / \mathrm{L}$ group compared with controls ( $p<0.05$ ); however, no such differences were observed for standard length.

Fecundity in $F_{0}$ fish. For reasons described previously, only fish from the $0.2-$ and $1.0-\mathrm{ng} / \mathrm{L}$ exposure groups and the controls were obviously male or female and therefore could be paired for assessment of reproductive effects. The results of the analysis of $\mathrm{F}_{0}$ fecundity are presented in Figure 1.

In fish exposed to $\mathrm{EE}_{2}$ for up to $301 \mathrm{~d}$ posthatch, there were no statistically significant reductions in the total number of eggs laid per treatment group (with eight individual breeding pairs), the mean number of eggs laid per female, and the mean number of eggs laid per female breeding day (Fig. 1). Therefore, the 301-d posthatch NOEC and LOEC values for $\mathrm{F}_{0}$ reproduction were considered to be $\geq 1.0$ and $>1.0 \mathrm{ng} / \mathrm{L}$, respectively.

From the fish depurated for $29 \mathrm{~d}$ after exposure to $\mathrm{EE}_{2}$ at $4.0 \mathrm{ng} / \mathrm{L}$ and paired with male control fish, four out of eight pairs of fish spawned successfully ( $241 \pm 131$ eggs per female, as mean $\pm S D, n=4$ ). These data suggested that only $50 \%$ of the fish depurated after exposure to $4.0 \mathrm{ng} / \mathrm{L}$ were functionally reproductive, even though histological analysis confirmed the presence of ovaries in all females $(n=8)$.

Hatchability of $F$, embryos. The hatching rate of control fish was $90.6 \pm 11.5 \%$ (mean $\pm \mathrm{SD}, n=4$ ) (Table 5). For: the fish exposed to $\mathrm{EE}_{2}$, hatching rates were $79.3 \pm 21.2 \%$ ( $n$ $=4)$ at $0.2 \mathrm{ng} / \mathrm{L}$ and $65.5 \pm 31.1 \%$ at $1.0 \mathrm{ng} / \mathrm{L}$. These exposure groups had no statistically significant differences from the controls. Therefore, the NOEC and LOEC values for $F_{1}$ fathead minnow embryo hatching success were considered to be \pm 1.0 and $>1.0 \mathrm{ng} / \mathrm{L}$, respectively.

Survival and growth of $F_{1}$ fish. Survival was $>90 \%$ at 32 d posthatch in all groups (Table 5), and there were no significant reductions in survival in any $\mathrm{EE}_{2}$ exposure group versus controls. Larval fish standard length was significantly reduced after exposure to $\mathrm{EE}_{2}$ at both 0.2 and $1.0 \mathrm{ng} / \mathrm{L}(p<0.05)$. $\mathrm{F}_{1}$ larval wet weight was also significantly reduced by approximately $10 \%$ after exposure to $\mathrm{EE}_{2}$ at $1.0 \mathrm{ng} / \mathrm{L}(p<0.05)$; however, the approximate $5 \%$ wet-weight reduction at $0.2 \mathrm{ng} /$ $L$ was not statistically significant. The sample size for these measurements varied between $55(1.0 \mathrm{ng} / \mathrm{L})$ and $115(0.2 \mathrm{ng} /$ L) because of different hatching rates and mortality.

Vitellogenin measurements. After $172 \mathrm{~d}$ posthatch, for fish that were too small to bleed, the vitellogenin level in the homogenate was expressed as micrograms vitellogenin per gram wet weight of fish. For larger fish, vitellogenin data were expressed as both micrograms per milliliter plasma and, for comparative purposes, also as micrograms vitellogenin per gram wet weight of fish (Fig, 2). Also, after $142 \mathrm{~d}$ posthatch, the stunted fish from the 64-ng/L $\mathrm{EE}_{2}$ exposure group were sampled for whole body vitellogenin analysis, giving $80 \pm 97 \mu \mathrm{g}$ vitellogenin per gram wet weight of fish (mean $\pm \mathrm{SD}, n=$ 12).

There was no concentration-related effect for females or males exposed to $\mathrm{EE}_{2}$ at $1.0 \mathrm{ng} / \mathrm{L}$. At $0.2 \mathrm{ng} / \mathrm{L}$, however; male fish showed a significant reduction in vitellogenin. Fish exposed to $4.0 \mathrm{ng} / \mathrm{L}$ could not be sexed; however, these indeterminate fish contained increased plasma vitellogenin levels between 0.35 and $34 \mu \mathrm{g} / \mathrm{ml}$ (Fig. 2). There were two distinctly different subgroups in which the vitellogenin levels were in the range of either male or female control fish. Body homogenate vitellogenin levels (mean value $110 \mu \mathrm{g} / \mathrm{g}$ ) at the $\mathrm{EE}_{2}$ concentration of $16 \mathrm{ng} / \mathrm{L}$ were markedly higher than those observed even in female control fathead minnows (mean equivalent to $11 \mu \mathrm{g} / \mathrm{g}$ ). These data therefore suggested that the 172-d posthatch NOEC and LOEC values for vitellogenin induction were 4.0 and $16.0 \mathrm{ng} / \mathrm{L}$.

Histological analysis of $F_{0}$ fish. Fish terminated at $56 \mathrm{~d}$ posthatch were evaluated for gonadal development and kidney lesions. Sex ratios following the gonadal development are given in Table 6. In control fish, all individuals analyzed at $56 \mathrm{~d}$ posthatch $(n=35)$ had immature gonads, although these were clearly differentiated into testis or ovary. In the $\mathrm{EE}_{2}$ exposure groups (1.0-16 ng/L), however, there was a dose-related increase in the co-occurrence of testicular and ovarian tissue within the same gonad (termed ovatestes) as shown in Figure 4. In the 64-ng/L exposed fish, no ovatestes were observed, although $94 \%$ of the fish appeared to be female.

The results indicated that at $\mathrm{EE}_{2}$ exposures up to $1 \mathrm{ng} / \mathrm{L}$, the developing fish remained in an approximate $50 \%$ male-tofemale ratio, whereas at higher concentrations, the proportion of males dropped dramatically, and the number of fish having ovatestes increased (except at the highest concentration). Further histopathological findings of the 56-d posthatch fish included kidney lesions (tubular degeneration and dilation, glomerulonephritis and glomeruloselerosis) at the two highest $\mathrm{EE}_{2}$ concentrations.

Fish terminated at $172 \mathrm{~d}$ posthatch included all treatments except the 64-ng/L. The fish at this highest test concentration had been terminated at 158 d posthatch (before pairing at 176 $\mathrm{d}$ posthatch) in view of their severe gross abnormalities. The fish for both 158 and $172 \mathrm{~d}$ posthatch were evaluated regarding gonadal development and kidney lesions in the same manner as conducted on their younger siblings at $56 \mathrm{~d}$ posthatch. Sex ratios according to gonad appearance are given in Table 6 . Almost all fish were histologically mature.

The sex ratio determined by histology showed a decrease in male animals at $1.0 \mathrm{ng} / \mathrm{L}$, while no males were observed at 

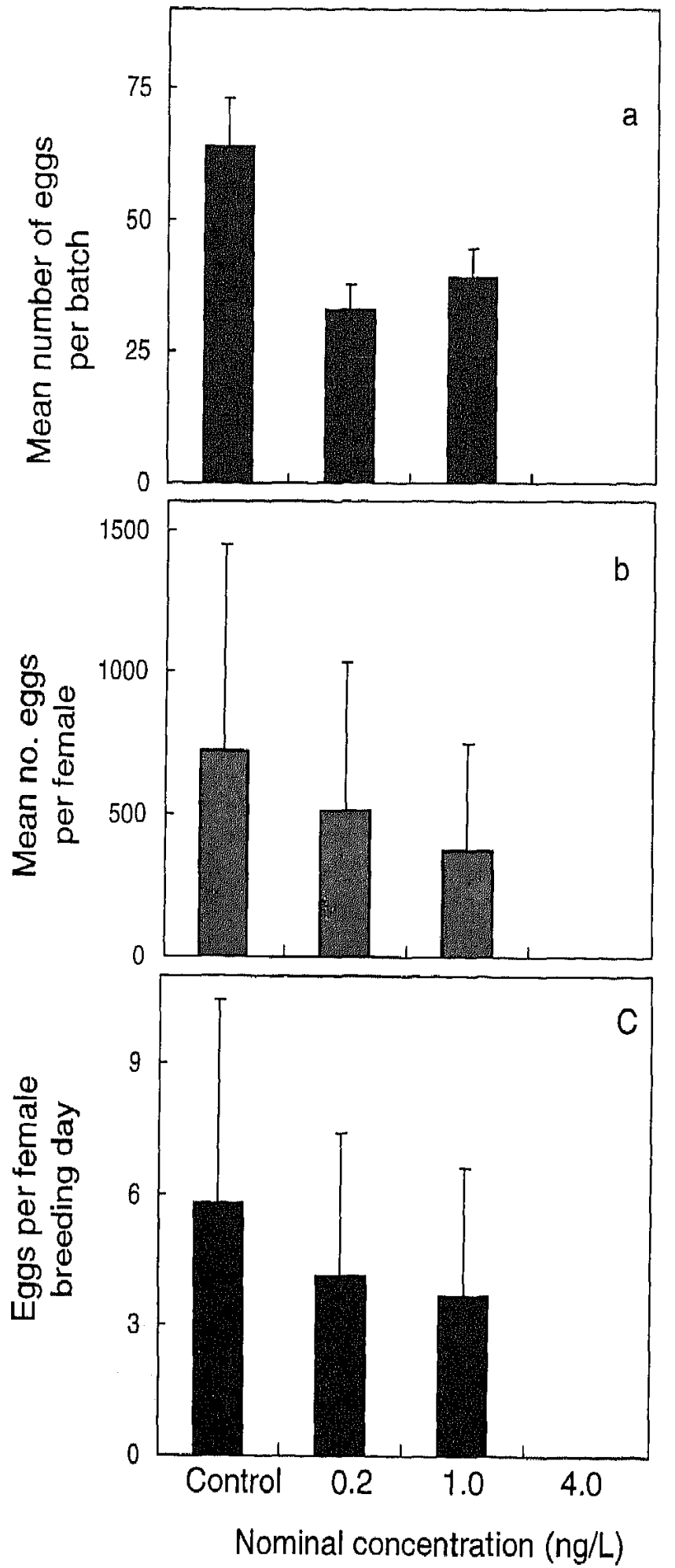

Fig. 1. Reproduction by fathead minnows exposed to ethinylestradion $\left(E_{2}\right)$ from 178 to $296 \mathrm{~d}$ posthatch. (a) Mean \pm standard error (SE) clata for number of eggs per batch in each treatment; (b) mean \pm SE data for number of eggs per female in each treatment; and (c) mean $\pm S E$ data for number of eggs per female per breeding day in each treatment.

$4.0 \mathrm{ng} / \mathrm{L}$ (Table 6). The number of investigated gonads at the 16 - and $64-n g / L$ concentration was very low $(n \pm 2)$, which precluded further analysis. Ovaries showed increasing degeneration at increasing concentrations of 16 and $64 \mathrm{ng} / \mathrm{L}$ compared to control (see Figs. 5 and 6). Testicular tissue showed mild stages of degeneration already at concentrations of $1 \mathrm{ng} /$ L. Extreme degeneration and tubular dilation in the kidneys, as well as glomerulonephritis, was observed in the highest $\mathrm{EE}_{2}$ concentration group. Fish in the other treatment groups showed only minor kidney lesions or normal tissue.

Histological analysis of $F_{1}$ fish. Fish of the $F_{1}$ generation from the early life-stage exposure were histologically analyzed for their gonadal development. Gonads were immature, as expected from fish of this age. The female gonads, however; were clearly distinguishable. Gonads appearing indifferent were presumed to be male, but this was a preliminary analysis, and more data are needed on the ontogeny of gonad development in this species. Although there was a slight increase in the number of females at 0.2 and $1.0 \mathrm{ng} / \mathrm{L}$ compared to the 50:50 ratio of female to male fish in the controls, this increase was not concentration related and was therefore not considered an $E_{2}$-related effect. No histopathological lesions were observed in liver and kidney in any $F_{1}$ fish exposed to $E_{2}$ under the conditions reported.

\section{DISCUSSION}

When evidence exists of a substance showing estrogenic activity in short-term screening assays, and where empirical or predictive data suggest exposure in aquatic ecosystems, it is clearly important to address potential long-term effects on the health of aquatic animals. Since $E_{2}$ may reach aquatic ecosystems [28], it was decided to evaluate the potential longterm effects on freshwater fish using a two-generation full lifecycle study. A summary of the critical LOEC and NOEC values obtained from the current FFLC study with $\mathrm{EE}_{2}$ is given in Table 7.

Life-cycle exposure of fathead minnows to $\mathrm{EE}_{2}$ had a strong impact on several key health indices, including gross development and growth, gonad development, sex determination, and reproductive maturity. Effects of $\mathrm{EE}_{2}$ on development in the early life stages of fathead minnows were most obvious, with a significant decrease in $\mathrm{F}_{0}$ larval growth (as standard length) after $28 \mathrm{~d}$ posthatch, giving LOEC and NOEC values of 16 and $4.0 \mathrm{ng} / \mathrm{L}$, respectively. After $56 \mathrm{~d}$ posthatch, the adverse effect of $\mathrm{EE}_{2}$ on larval growth was increasingly severe, giving LOEC and NOEC values of 4.0 and $1.0 \mathrm{ng} / \mathrm{L}$, respectively. The $F_{0}$ growth impairment after 56 d posthatch at 4.0 $\mathrm{ng} / \mathrm{L}$ was concomitant with the induction of ovatestes ( $11 \%$ in treated fish vs $0 \%$ in controls) (Table 6). These observations demonstrated the value of the fish growth as an apical endpoint for measuring the adverse biological effect of potent xenoestrogens. Additionally, larval growth retardation was a valuable early indicator for the longer-term estrogenic effects $\mathrm{EE}_{2}$ produced on the sexual development of fathead minnows. In contrast, the larval fish growth endpoint has traditionally been considered to be nonspecific for particular toxic mechanisms (estrogenic or otherwise) and is widely used as a general stress response [29]. Furthermore, impacts of endocrine- and nonendocrine-mediated reductions in fish growth are of ecological importance, with reduced growth rates being associated with reduced fitness [30].

Continued exposure of $F_{0}$ fathead minnows to $\mathrm{EE}_{2}$ led to a further general retardation of maturation and development of secondary sexual characteristics. Fish exposed to $4.0 \mathrm{ng} / \mathrm{L}$ showed no male secondary sex characteristics at any age (while the control fish and the fish at $\leq 1.0 \mathrm{ng} / \mathrm{L}$ became sexually mature after $120 \mathrm{~d}$ posthatch), and at $\geq 16 \mathrm{ng} / \mathrm{L}$, fish showed abnormal development in respect of growth and secondary sexual characteristics. After $172 \mathrm{~d}$ posthatch, histological analysis showed that all fish from the 4.0-ng/L group had gonads containing only ovarian tissue (no testis observed) (Table 6). 
Table 5. Effect of ethinylestradiol $\left(E_{2}\right)$ exposure on $F_{1}$ fathead minnow embryo hatching, survival and growth"

\begin{tabular}{|c|c|c|c|c|c|}
\hline \multirow[b]{2}{*}{ Fish } & \multirow{2}{*}{$\begin{array}{c}\text { Exposure } \\
\text { day }\left(\mathrm{DPH}^{\mathrm{b}}\right)\end{array}$} & \multirow[b]{2}{*}{ Endpoint } & \multicolumn{3}{|c|}{ Nominal $\mathrm{EE}_{2}$ concentration (ng/L) } \\
\hline & & & Control & 0.2 & 1.0 \\
\hline \multirow[t]{4}{*}{$F_{1}$} & 1 & $\%$ Hatching $(n \leq 500)$ & $90.6 \pm 11.5$ & $79.3 \pm 21.2$ & $65.5 \pm 31.1$ \\
\hline & 28 & Survival $(n=100)$ & $95.0 \pm 6.00$ & $94.3 \pm 8.27$ & $92.0 \pm 13.9$ \\
\hline & 28 & Larval standard length (mm) & $22.4 \pm 1.95$ & $21.5 \pm 2.46^{*}$ & $20.9 \pm 2.05^{*}$ \\
\hline & 28 & Larval wet weight ( $\mathrm{mg}$ ) & $179 \pm 46.8$ & $170 \pm 45.9 *$ & $161 \pm 42.0^{*}$ \\
\hline
\end{tabular}

"Values as mean \pm standard deviation.

1) $\mathrm{DPH}=$ days posthatch.

* = significantly less than control group $(p<0.05)$.

Following a 29-d depuration period, fish from the 4.0-ng/L exposure group were paired with control males, and four out of eight of these pairs were shown to be fertile $(241 \pm 131$ eggs per female, as mean $\pm S D$ ). Since there was no method available for genetic sex determination in fathead minnows, it was uncertain whether the failure to spawn in the other four breeding pairs (phenotypic females from $4.0-n g / L$ exposure group and males from control group) was related to $\mathrm{EE}_{2}$ exposure affecting the development of the sexual phenotype.

It is common knowledge in aquaculture that exposure to
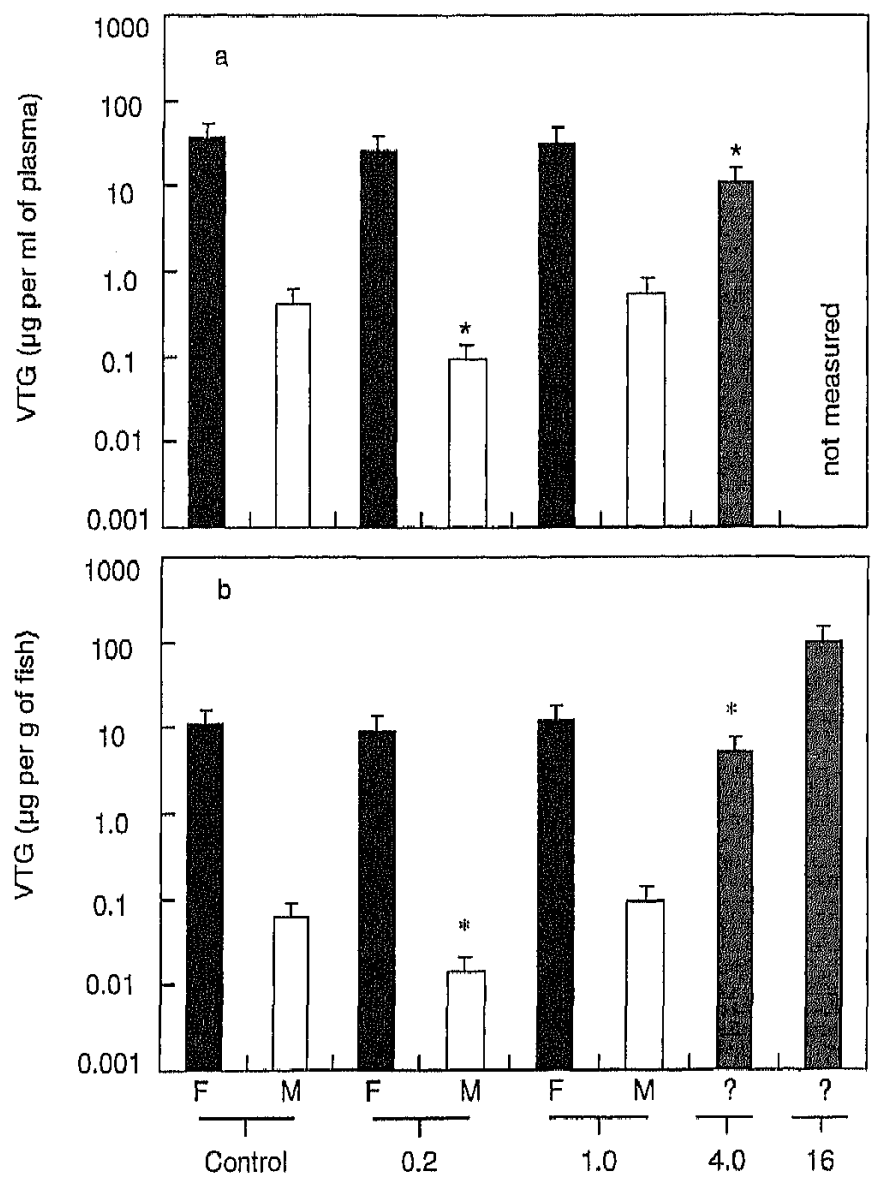

Nominal concentration ( $\mathrm{ng} / \mathrm{L}$ )

Fig. 2. (a) Plasma vitellogenin (VTG) concentrations (as mean \pm standard deviation [SD]) in fathead minnows exposed for $172 \mathrm{~d}$ posthatch to ethinylestradion $\left(\mathrm{EE}_{2}\right)(n=12)$. (b) Whole body homogenate vitellogenin concentrations (as mean \pm SD) in fathead minnows exposed for $172 \mathrm{~d}$ posthatch to $\mathrm{EE}_{2}$. Female, male, and indeterminate fish are shown by $\mathrm{F}, \mathrm{M}$, and ?, respectively, * Significantly different from vitcllogenin values in control male fish $(p<0.05)$. Note that after $142 \mathrm{~d}$ posthatch, the stunted fish from the $64-1 \mathrm{ng} / \mathrm{L}$ EE 2 exposure group were also sampled for whole body vitellogenin analysis, giving $80 \pm 97 \mu \mathrm{g}$ vitellogenin per gram wet weight of fish (nean + SD, $n=12$ ). the natural estrogen $17 \beta$-estradiol or $\mathrm{EE}_{2}$ has a feminizing effect on fish. For example, Piferrer and Donaldson [20] feminized chinook salmon (Oncorhynchus tshawytscha) by single immersions of larvae in water containing $400 \mu \mathrm{g} / \mathrm{L}$ of $\mathrm{EE}_{2}$ or $17 \beta$-estradiol for a few hours directly after hatching and before sexual differentiation of the gonads. Although the fathead minnow study used much lower concentrations of $\mathrm{EE}_{2}$, it was not surprising that the long-term exposure, throughout embryolarval development, produced such a dramatic feminization of the gonads after 56 and 172 d posthatch (Table 6).

Fecundity is widely considered to be a key parameter affecting the sustainability of fish populations. Recent workshops have highlighted the need to address the impacts of endocrine disruptors on the demographics and reproductive health of fish populations where developmental or reproductive dysfunction is occurring $[31,32]$. In principle, the evaluation of the reproductive effects of $\mathrm{EE}_{2}$ represented a key goal in the FFLC study with fathead minnows. The fecundity endpoint related to egg laying; however, it was not a very sensitive parameter (Fig, 1). Although there seemed to be a general trend toward a decrease in egg production at 0.2 and $1.0 \mathrm{ng} /$ $\mathrm{L}$, the apparent differences from the control were not statistically significant. The reason for the low sensitivity of this parameter was the large variation in egg production by individual pairs of lathead minnows (Fig. 1). For example, the breeding pairs $(n=8)$ in the control group produced between 0 and 1,977 eggs, while at $1.0 \mathrm{ng} / \mathrm{L}$, fish produced between 0 and 1,763 eggs over 176 to 301 d posthatch. On the other hand, at $1.0 \mathrm{ng} / \mathrm{L}$, only one pair of fish produced more than $400 \mathrm{eggs}$, while at zero and $0.2 \mathrm{ng} / \mathrm{L}$, four and five pairs produced in excess of 400 eggs, respectively. Taking into account the large variability of this parameter, the interpretation of small reductions in egg production was difficult, and small-

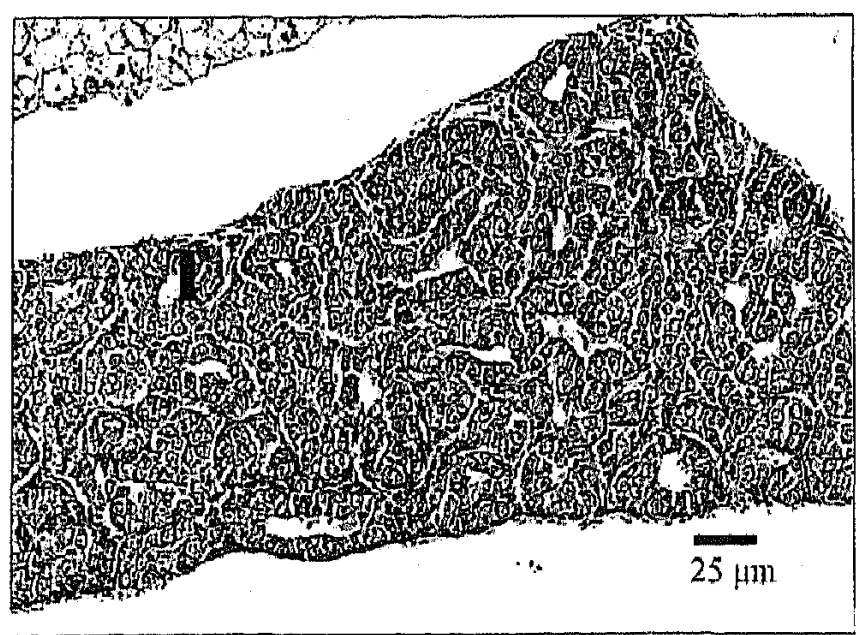

Fig. 3. Gonads (testis) of control animal at day 56. 
Table 6. Sex ratios based on histological analysis of fathead minnows exposed to ethinylestradiol $\left(\mathrm{EE}_{2}\right)$

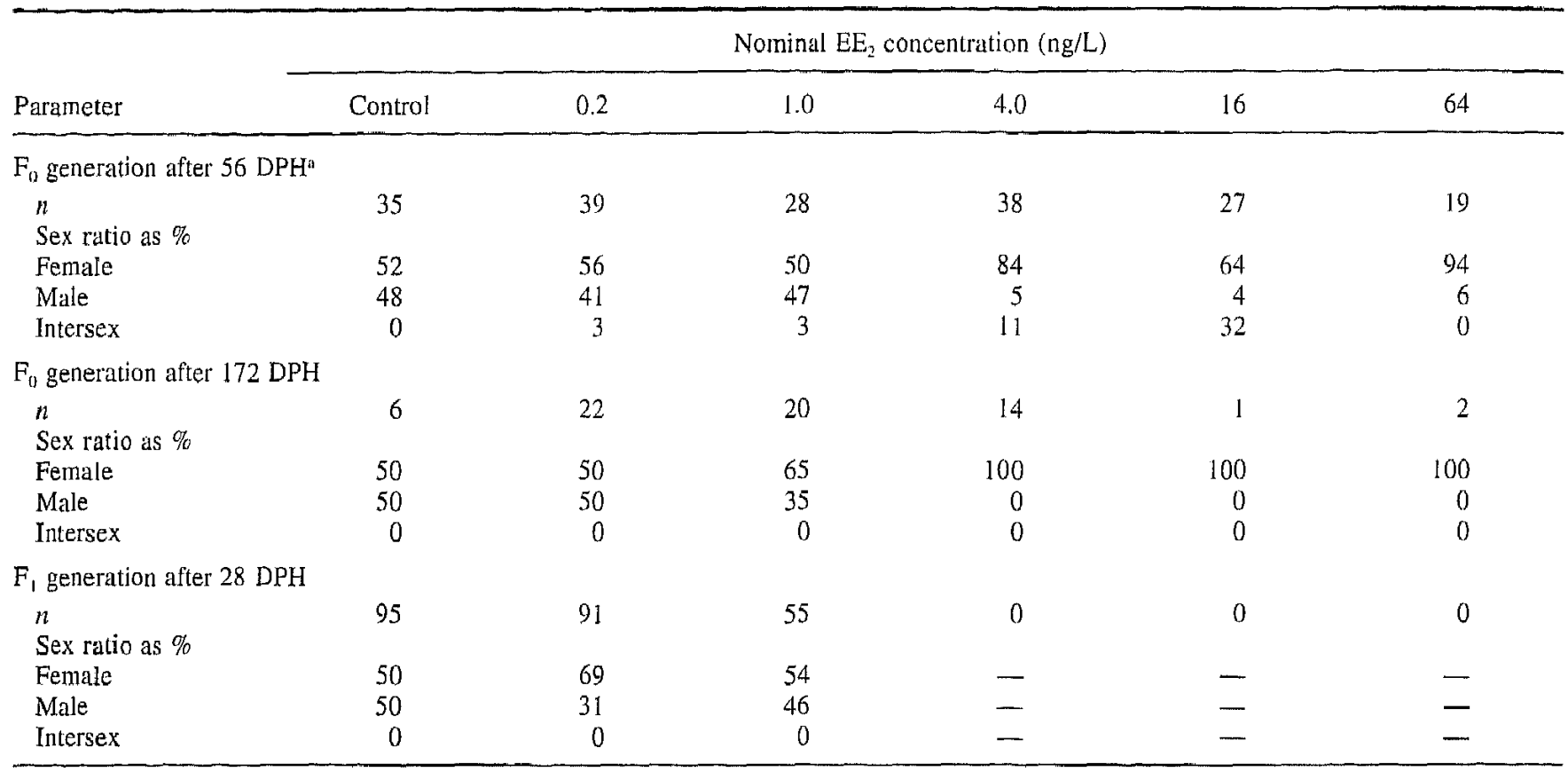

"DPH $=$ days posthatch.

scale changes in this endpoint were likely to be of relatively little biological relevance. For comparison, the historical database for fathead minnow life-cycle studies (with individual breeding pairs) conducted at the Brixham Environmental Laboratory shows that the number of eggs per pair (mean $\pm S D$ ) has ranged in recent years from a control minimum of $353 \pm$ 345 up to a maximum of $1,552 \pm 1,105$ eggs per pair [33]. Even when following the recommended regulatory guidelines, this level of variability is an inherent problem when studying toxicant impacts on the fecundity of batch-spawning cyprinids. Indeed, recognizing this problem, recommendations have been made for developing other designs of fish reproduction studies that will not incur the problems of existing FFLC study designs [34].

Histological evaluation showed that all $\mathrm{F}_{0}$ fish exposed to $\mathrm{EE}_{2}$ at $\leq 1.0 \mathrm{ng} / \mathrm{L}$ had male or female gonads that were in a mature reproductive state (in these fish, no occurrence of ovatestes was noted). On the other hand, slight degenerations in male gonadal tissue was observed at a concentration of $1 \mathrm{ng} /$ L. Nevertheless, the concomitant decrease of male-to-female

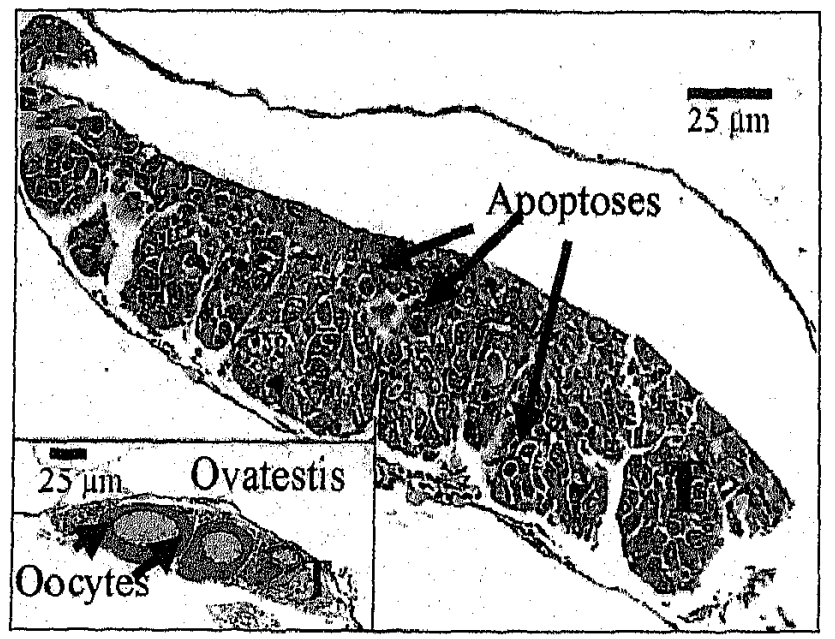

Fig. 4. Gonads (testis) of animal treated with $4 \mathrm{ng} / \mathrm{L}$ ethinylestradiol $\left(\mathrm{EE}_{2}\right)$ at day 56 showing atrophy and apoptoses (arrows). Insert showing gonad with ovatestis. ratio and of egg production at $1.0 \mathrm{ng} / \mathrm{L}$ warrants further consideration. In our evaluation the magnitude of the changes does not suggest that they are indicative of a relevant effect of $\mathrm{EE}_{2}$ on fathead minnow at a population level. In $F_{0}$ fish exposed to $4.0 \mathrm{ng} / \mathrm{L}, 100 \%$ of individuals had all female gonads, supporting the conclusion that there was a dramatic inhibition of breeding after long-term exposure to $\mathrm{EE}_{2}$ at $>1.0 \mathrm{ng} / \mathrm{L}$.

In terms of evaluating estrogenic biomarkers to $\mathrm{EE}_{2}$ exposure, key challenges at the outset of the FFLC study were, first, could vitellogenin be accurately measured in such small fish as the fathead minnow and, second, what was the correlation between plasma vitellogenin levels, induction of intersex gonads and gross development, growth, and reproduction? The first issue was successfully addressed by adaptation of an heterologous RIA based on antisera raised to carp (Cyprinus carpio) vitellogenin and shown to cross-react quantitatively with fathead minnow vitellogenin in both RIA and enzyme-linked immunosorbent assay methods [24,35]. Regarding the second question, data from the $\mathrm{EE}_{2}$ FFLC study suggested that significantly elevated vitellogenin levels (in either fish plasma or whole fish homogenates for those fish too small to bleed) were consistent with certain other biological findings within the

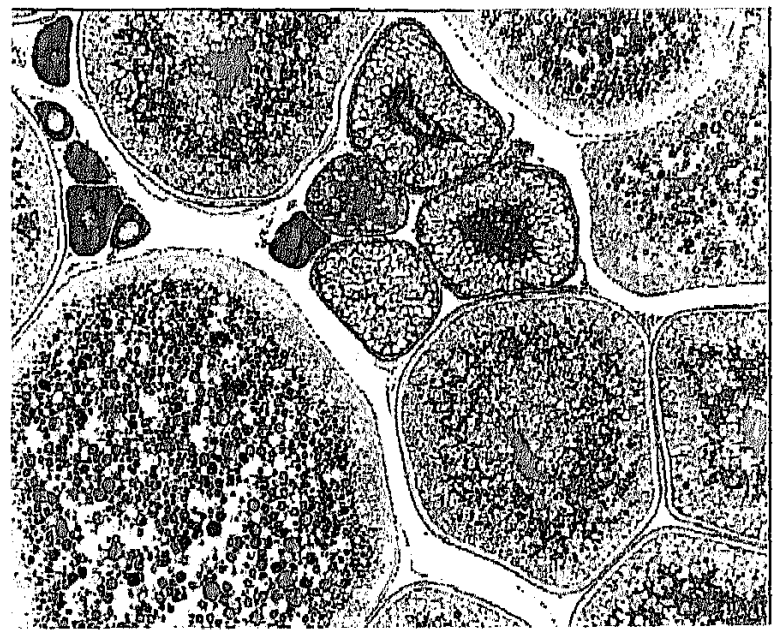

Fig. 5. Ovary of control animal at day 178. 


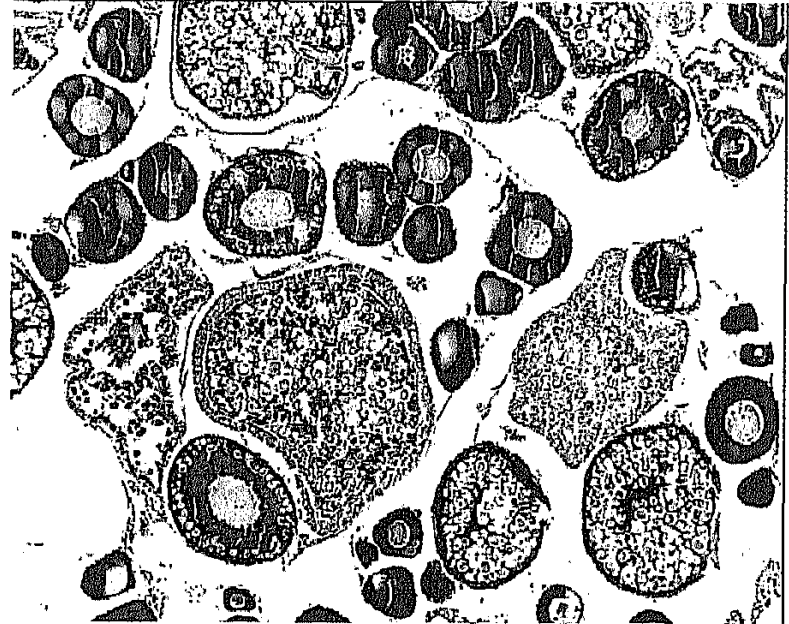

Fig. 6. Ovary of animal treated with $16 \mathrm{ng} / \mathrm{L}$ esthinylestradion $\left(\mathrm{EE}_{2}\right)$ at day 172 showing predominantly primary and secondary follicles and various stages of follicle atresia.

study. After 172-d posthatch exposure to $\mathrm{EE}_{2}$ at 0.2 and 1.0 $\mathrm{ng} / \mathrm{L}$, vitellogenin levels for adult males and females were in the range observed in the controls (male plasma $0.410 \pm 0.188$ $\mu \mathrm{g} / \mathrm{ml}$, female plasma $36 \pm 17 \mu \mathrm{g} / \mathrm{ml}$, as mean $\pm \mathrm{SD}$ ) and were typical of those reported in other studies using this assay method [36,37]. Since the fish from the $4.0-\mathrm{ng} / \mathrm{L}$ exposure group could not be sexed externally (and were all phenotypic females based on gonad histology), the results of the vitellogenin levels in this group were difficult to interpret. In the 4.0ng/L exposure group, five out of 11 fish had relatively low vitellogenin levels at $172 \mathrm{~d}$ posthatch (similar to those of the male control fish), while the remaining six fish had markedly higher vitellogenin concentrations that were similar to vitel- logenin values for adult female control fish. This pattern of vitellogenin levels may have explained why only half the phenotypic females used for the depuration evaluation $(4.0-\mathrm{ng} / \mathrm{L}$ exposure group only) were ultimately able to produce eggs when paired with control group males.

Based on vitellogenin concentrations in whole body homogenates, there was not a linear relationship between the high levels of vitellogenin induction observed after $\mathrm{EE}_{2}$ exposure at 16 or $64 \mathrm{ng} / \mathrm{L}$ for up to $172 \mathrm{~d}$ posthatch (Fig. 2). There was, however, more than a threefold increase in vitellogenin levels at 16 and $64 \mathrm{ng} / \mathrm{L}$ compared to control adult females, indicating that vitellogenin induction was correlated with developmental and reproductive impairment. Adverse effects in fish exposed to concentrations of $\mathrm{EE}_{2} \geq 16 \mathrm{ng} / \mathrm{L}$ were probably due to accumulation of vitellogenin in the kidneys, leading to renal failure and consequent loss of homeostasis. Similar findings have been reported in salmonid aquaculture [38]. These findings strengthen the rationale for the further evaluation of vitellogenin as an estrogen exposure biomarker, for application and linkage between both field and laboratory studies [39].

The FFLC data indicated that extremely high vitellogenin levels occurred only in those exposure groups which also exhibited severe developmental and reproductive impaiment, with NOEC values for all these endpoints being in close agreement (Table 7). Equally, fish developing and reproducing normally also did not show abnormal levels of vitellogenin in their tissues. While published data suggest that vitellogenin induction is an extremely sensitive exposure biomarker for exogenous estrogens, many such studies are based solely on relatively short exposure periods of days to weeks. For immersion exposures up to $28 \mathrm{~d}$, Purdom et al. [1] and D.A.

Table 7. Summary of life-cycle effects in fathead minnows exposed to ethinylestradiol $\left(\mathrm{EE}_{2}\right)$

\begin{tabular}{|c|c|c|c|c|}
\hline & $\mathrm{DPH}^{\mathrm{a}}$ & Parameter & $\begin{array}{c}\text { LOEC } \\
\text { (ng/L) }\end{array}$ & $\begin{array}{c}\text { NOEC } \\
(\mathrm{ng} / \mathrm{L})\end{array}$ \\
\hline \multirow[t]{3}{*}{$F_{01}$} & 1 & Embryo hatch & $>64$ & $\geq 64$ \\
\hline & 28 & Embryo-Jarval survival & 64 & 16 \\
\hline & 28 & Larval standard length & 16 & 4.0 \\
\hline \multirow[t]{4}{*}{$F_{0}$} & 56 & Juvenile survival & 64 & 16 \\
\hline & 56 & Juvenile standard length & 4.0 & 1.0 \\
\hline & 56 & Juvenile wet weight & $>64$ & $\geq 64$ \\
\hline & 56 & Gonad histology (ovatestis present) & 4.0 & 1.0 \\
\hline \multirow{8}{*}{$F_{0}$} & 172 & Gonad histology (ovotestis present) & 4.0 & 1.0 \\
\hline & 172 & Vitellogenin induction & 16 & 4.0 \\
\hline & $176-301$ & Adult survival & $>1.0$ & $\geq 1.0$ \\
\hline & 301 & Female standard length & $>1.0$ & $\geq 1.0$ \\
\hline & 301 & Male standard length & $>1.0$ & $\geq 1.0$ \\
\hline & 301 & Feinale wet weight & 1.0 & $0.2^{\mathrm{ll}}$ \\
\hline & 301 & Male wet weight & $>1.0$ & $\geq 1,0$ \\
\hline & $176-301$ & Egg production ${ }^{\mathrm{C}}$ & $>1.0$ & $\geq 1.0$ \\
\hline \multirow[t]{8}{*}{$\mathrm{F}_{1}$} & 1 & Embryo hatch & $>1.0$ & $\geq 1.0$ \\
\hline & 28 & Embryo-larval survival & $>1.0$ & $\geq 1.0$ \\
\hline & 28 & Larval standard length & 0.2 & $<0.2^{r}$ \\
\hline & 28 & Larval wet weight & 1.0 & $0.2^{\mathrm{r}}$ \\
\hline & 28 & Gonad histology & 4.0 & 1.0 \\
\hline & $1-301$ & Summary: statistically derived & 0.2 & $<0,2$ \\
\hline & $1-301$ & Suntmary: biologically derived & 4.0 & 1.0 \\
\hline & $1-301$ & NOEC & - & 1,0 \\
\hline
\end{tabular}

"DPH = days posthatch.

" $\mathrm{LOEC}=$ lowest-observed-effect concentration.

. NOEC $=$ No-observed-effect concentration.

"Not considered compound related.

- Based on number eggs per female breeding day as the most sensitive reproductive parameter.

r Not considered biologically relevant since it is in the historical control range. 
Sheahan et al. (unpublished data) reported plasma vitellogenin increases in proportion to $\mathrm{EE}_{2}$ concentration in juvenile rainbow trout (Oncorhynchus mykiss), starting with $\mathrm{EE}_{2}$ concentrations as low as $0.1 \mathrm{ng} / \mathrm{L}$. In contrast to such short-term studies, the long-term exposure of fish to potent estrogens such as $\mathrm{EE}_{2}$, as in this FFLC study, may have resulted in a somewhat less sensitive vitellogenin response because of endocrine feedback loops and associated physiological regulating mechanisms within fish.

For the $F_{1}$ larvae, standard length was significantly reduced after exposure to $\mathrm{EE}_{2}$ at both 0.2 and $1.0 \mathrm{ng} / \mathrm{L}(p<0.05)$; however, it was debatable whether such slight length reductions (of 4.0 and $6.7 \%$, respectively) represented a key adverse biological effect (Table 6 ). The $F_{1}$ larval wet weight was also significantly reduced by approximately $10 \%$ after exposure at $1.0 \mathrm{ng} / \mathrm{L}(p<0.05)$; however, the approximate $5 \%$ wet-weight reduction at $0.2 \mathrm{ng} / \mathrm{L}$ was not statistically significant. For comparison, the historical database for fathead minnow life-cycle studies conducted at Brixham indicates that comparable larval standard lengths typically range from 16.5 to $22.4 \mathrm{~mm}$, while control larval wet weights range from 58 to $179 \mathrm{mg} \mathrm{[32].}$ Additionally, the gonadal histology did not indicate any effect on the sex determination at this stage. Therefore, the effects on length and weight up to $1 \mathrm{ng} / \mathrm{L}$ are not considered biologically relevant.

A complication of the evaluation of the test regarding the $F_{1}$ generation was in terms of the selection of embryos from the eight breeding pairs per treatment (control, 0.2 , and 1.0 $\mathrm{ng} / \mathrm{L}$ only). Since the starting dates for the $\mathrm{F}_{\mathrm{f}}$ early life-stage studies were harmonized for all treatments, spawnings from $F_{0}$ pairs at the scheduled $F_{1}$ study start date were of necessity selected in preference to a random selection of eggs from across the various spawning patterns of the three treatments. For example, in the control treatment, six from eight breeding pairs supplied eggs for hatching trials rather equally. In contrast, at the 1.0-ng/L treatment, seven from eight breeding pairs supplied eggs; however, one pair (termed "B3") supplied the majority of all eggs. This was an unavoidable bias in starting the $F_{1}$ early life-stage studies, whereby not all progeny of every $F_{0}$ breeding pair (eight per treatment) had an equal chance to be allocated to the $F_{1}$ early life-stage study. In view of these issues, further caution should be applied in interpreting the biological relevance of the statistical evaluation relating to the $F_{1}$ growth data. Taken as a whole, it was therefore considered that for all the endpoints monitored during the $\mathrm{EE}_{2}$ FFLC study, the overall biologically derived LOEC and NOEC values were 4.0 and $1.0 \mathrm{ng} / \mathrm{L}$, respectively (Table 7).

In terms of risk evaluation, the potential exposure of fish populations to $\mathrm{EE}_{2}$ can be estimated using the modeling and analytical data published by various author's. Recent modeling data by Williams et al. [40] have suggested average $\mathrm{EE}_{2}$ concentrations of between 0.024 and $0.038 \mathrm{ng} / \mathrm{L}$; however, predicted average concentrations increased by 4 - to 10 -fold under low-flow conditions. Aherne and Briggs [28] reported $\mathrm{EE}_{2}$ concentrations of $<1$ to $7.0 \mathrm{ng} / \mathrm{L}$ in sewage treatment work effluents and 2 to $15 \mathrm{ng} / \mathrm{L}$ in surface waters. More recently, effluents from seven sewage treatment works treating domestic wastewater in England contained $\mathrm{EE}_{2}$ concentrations of $<0.2$ to $7.0 \mathrm{ng} / \mathrm{L}$ [10]. Ternes et al. [13] reported $\mathrm{EE}_{2}$ concentrations in treated effluents from German sewage treatment works of $1.0 \mathrm{ng} / \mathrm{L}$ (median) and $<0.5 \mathrm{ng} / \mathrm{L}$ (limit of determination) for all samples in German rivers, while Larsson et al. [12] reported Swedish sewage treatment works effluent to contain $\mathrm{EE}_{2}$ at up to $4.5 \mathrm{ng} / \mathrm{L}$. In a recent study, W. Kalbfus et al. (unpublished data) monitored wastewater before and after treatment, together with surface and drinking waters, with approximately 80 samples gathered during 1997 from various locations in Germany. Sewage treatment works effluents contained median $\mathrm{EE}_{2}$ concentrations of $0.2 \mathrm{ng} / \mathrm{L}$ (range $<0.05-4.0 \mathrm{ng} / \mathrm{L}$ ), while only six of 79 surface water samples had $\mathrm{EE}_{2}$ concentrations $>0.1 \mathrm{ng} / \mathrm{L}$ (maximum of $2.0 \mathrm{ng} / \mathrm{L} ; 90 \mathrm{th}$ percentile $0.1 \mathrm{ng} / \mathrm{L}$ ). Therefore, the recent data from Europe indicate that surface water concentrations of $\mathrm{EE}_{2}$ are generally below $0.5 \mathrm{ng} / \mathrm{L}$, and it is expected that the concentrations are in most cases $<0.1$ $\mathrm{ng} / \mathrm{L}$.

In summary, it can be concluded that the life-cycle exposure of the fathead minnow to low concentrations of $\mathrm{EE}_{2}$ produced concentration-related impacts on growth, development, sexual development, and reproductive health. Induction of plasma vitellogenin together with histological changes in the gonads and reduced $F_{0}$ larval growth were valuable indicators for the long-term developmental and reproductive effects of $\mathrm{EE}_{2}$, although differing in sensitivity. Overall, for all the endpoints monitored during the $\mathrm{EE}_{2} \mathrm{FFLC}$ study, the biologically derived NOEC was $1.0 \mathrm{ng} / \mathrm{L}$. These data, together with those for other aquatic organisms, should be used to conduct an ecological risk assessment for $\mathrm{EE}_{2}$ entering surface waters.

Acknowledgement-This work was designed and lunded by Schering AG, Berlin, Germany. Our thanks to J.E. Caunter, M.D.R. Field, and E. Gillings of Brixham Environmental Laboratory and to T. StegerHartmann and T. Weiser of Schering AG.

\section{RETERENCES}

1. Purdom CE, Hardiman PA, Bye VJ, Eno NC, Tyler CR, Sumpter JP. 1994. Estrogenic effects of effluent from sewage treatment works. Chem Ecol 8:275-285.

2. Jobling $S$, Nolan M, Tyler CR, Brighty G, Sumpter JP. 1998. Widespread sexual distuption in wild fish. Environ Sci Technol $32: 2498-2506$.

3. Sumpter JP. 1995. Feminized responses in fish to environmental estrogens, Toxicol Lett 82/83:737-742.

4. Folmar LC, Denslow NC, Rao V, Chow M, Crain DA, Enblon J, Marcino J, Guillette LJ Jr. 1996. Vitellogenin induction and reduced serum testosterone concentrations in feral male carp $(C y-$ prinus carpio) captured near a major metropolitan sewage treattment plant. Environ Health Perspect 104:1096-1101.

5. Giesy JP, Snyder EM. 1998. Xenobiotic modulation of endocrine function in fishes. In Kendall RI, Dickerson RL, Giesy JP, Suk WP, eds, Principles and Processes for Evaluating Endocrine Disruption in Wildlife. SETAC, Pensacola, FL, USA, pp 155-237.

6. Jobling S, Sheahan DA, Osborne JA, Matthiessen P, Sumpter JP. 1996. Inhibition of testicular growth in rainbow trout (Oncorhynchus mykiss) exposed to estrogenic alkylphenolic chemicals. Environ Toxicol Chem 15:194-202.

7. Routledge EJ, Sumpter JP. 1996. Oestrogenic activity of surfactants and some of their degradation products assessed using a recombinant yeast screen. Environ Toxicol Chem 15:241-248.

8. Harries JE, et al. 1997. A survey of estrogenic activity in United Kingdom inland waters. Environ Toxicol Chem 15:1993-2002.

9. Harries JE, Sheahan DE, Jobling S, Matthiessen P, Neall $M$, Sumpter JP, Taylor T, Zaman N. 1997. Estrogenic activity in five United Kingdom rivers detected by measurement of vitellogenesis in caged male trout. Environ Toxicol Chem 16:534-542.

10. Desbrow C, Routledge EJ, Brighty GC, Sumpter JP, Waldock MJ. 1998. Identification of estrogenic chemicals in sewage treatment works effluent. 1. Chemical fractionation and in vitro biological screening. Environ Sci Technol 32:1549-1558.

11. Routledge EJ, Sheahan D, Desbrow C, Brighty GC, Waldock M, Sumpter JP. 1998. Identification of estrogenic chemicals in sewage treatment works effiuent, 2 . In vivo responses in trout and roach. Environ Sci Technol 32:1559-1565.

12. Larsson DGJ, Adolfsson-Erici M, Parkkonen J, Petterson M, Berg 
AH, Olsson P-E, Förlin L. 1999. Ethinyloestradiol--an undesired fish contraceptive? Aquat Toxicol 45:91-97.

13. Ternes TA, Stumpf M, Mueller J, Harberer K, Wilken R-D, Servos M. 1999. Behaviour and occurrence of estrogen in municipal sewage treatment plants-Investigations in Germany, Canada and Brazil. Sci Total Environ 225:81-90.

14. Stumpf M, Ternes TA, Haberer K, Baumann W. 1996. Determination of natural and synthetic estrogens in sewage plants and river water. Vom Wasser 87:25 [-261.

15. Arcand-Hoy LD, Nimrod AC, Benson WH. 1998. Endocrine modulating substances in the environment-Estrogenic effects of pharmaceutical products. Int $J$ Toxicol 17:139-158.

16. Orme MLE, Bock DJ, Brekenridge AM. 1983. Clinical pharmacokineties of oral contraceptive steroids. Clin Pharmacokinet 8:93-136

17. Shore LS, Gurevitz M, Shermesh M. 1993. Estrogen as an environmental pollutant. Bull Environ Contam Toxicol 51:361-366.

18. Redding JM, Patiño R. 1993. Reproductive physiology. In Evans DH, ed, The Physiology of Fishes. CRC Marine Sciences Series, Boca Raton, FL, USA, pp 503-534.

19. Sumpter JP, Jobling S. 1995. Vitellogenesis as a bionarker for estrogenic contamination of the aquatic environment. Environ Health Perspect 103:173-178.

20. Piferrer F, Donaldson EM. 1992. The comparative cffectiveness of the natural and synthetic estrogen for the direet feminisation of chinook salmon. Aquaculture 106:183-193.

2I. U.S. Environmental Protection Agency. 1986. Fish life-cycle toxicity tests. EPA 540/9-86-137. Hazard Evaluation Division, Office of Pesticide Programs, Washington DC.

22. McKim JM. 1977. Evaluation of tests with early life-stages of fish for predicting long term toxicity. J Fish Res Board Can 34: $1134-1154$.

23. Roberts R.T. 1989. Fish Pathology. Bailliere Tindall, London, UK, pp 467.

24. Tyler CR, Vándereerden B, Jobling S, Panter G, Sumpter JP. 1996. Mcasurement of vitellogenin, a biomarker for exposure to estrogenic chemicals, in a wicle variety of cyprinid fish. $J$ Comp Physiol $B$ 166:418-426.

25. Tyler CR, Lancaster P. 1993. Isolation and characterisation of the receptor for vitellogenin from the follicles of the rainbow trout (Oncorhynchus mykiss). J Comp Physiol B 163:225-233.

26. Steel RG. 1959. A multiple comparison rank sum test: Treatments versus control. Biometrics 15:560-572.

27. Hollander M, Wolfe DA. 1973. Non-Parametrie Statistical Methods, John Wiley \& Sons, New York, NY, USA, pp 185.

28. Aherne GW, Briggs R. 1989. The relevance of the presence of certain synthetic steroids in the aquatic environment. $J$ Pharmacokinet Pharmacol 41:735-736.

29. Pankhurst NW, van der Kraak G. 1997. Effects of Stress on Reproduction and Growth of Fish. Seminar Series 62. Cambridge University Press, Cambridge, UK, pp 73-95.

30. Pepin P. 1990. Effect of temperature and size on development, mortality and survival rates of the peligic early life history stage: of marine fish. Can J Fish Aquat Sci 48:503-518.

31. Rolland RM, Gilbertson M, Peterson RE. 1997. Chemically induced alterations in functional development and reproduction of' fishes, Proceedings, 1995 Wingspread Conference, Racine, WI, USA, July 21-23, SETAC, Pensacola, FL, USA.
32. Ankley $G$, et al. 1998. Overview of a workshop on screening methods for detecting potential (anti-) estrogenic/androgenic chemicals in wildlife. Environ Toxicol Chem 17:68-87.

33. Hutchinson TH. 1999. Fathead minnow full life-cycle studies: Summary of control data for survival, growth and reproduction. AstraZeneca Brixham Environmental Laboratory Report BLS2474/B. AstraZeneca, Brixham, UK,

34. European Centre for the Ecotoxicology and Toxicology of Chemicals. 1999. Screening and testing methods for ecotoxicological effects of potential endocrine disruptors: Response to the EDSTAC recommendations and a proposed alternative appronch. ECETOC Document 39. Brussels, Belgium.

35. Tyler CR, van Aerle R, Hutchinson TH, Maddix S, Tripp H. 1999. An in vivo testing system for endocrine disruptors in fish early life-stages using induction of vitellogenin. Environ Toxicol Chem 18:337-347.

36. Panter GH, Thompson RS, Sumpler JP. 1998. Adverse reproductive effects in male fathead minnows (Pimephales promelas) $\mathrm{ex}$ posed to environmentally relevant concentrations of the natural estrogens, oestradiol and oestrone. Aquat Toxicol 42:243-253.

37. Panter GH, Thompson RS, Sumpler JP. 1999. Transformation of a non-estrogenic steroid metabolite to an estrogenically active substance by minimal bacterial activity. Chemosphere 38:3579 3596 .

38. Herman RL, Kincaid HL. 1988. Pathological effects of orally administered estradiol to rainbow troul. A quaculture 72:165-172.

39. Campbell PM, Hutchinson TH. 1998. Wildlife and endocrine disruptors: Requirements for hazard identification. Environ Toxicol Chem 17:127-135.

40. Williams RJ, Jürgens MD, Johnson AC, 1999. Initial predictions of the concentrations and distribution of $17 \beta$-oestradiol, oestrone and ethinylestradiol in three English rivers. Water Res 33:16631671.

\section{APPENDIX}

Summary of key periods included in the ethinylestradiol fish full life-cycle study

Study period

(ds post-hatch) Assessment endpoint

\begin{tabular}{|c|c|}
\hline$-4-1$ & $F_{0}:$ Embryo development and hatcling \\
\hline $1-28$ & $\begin{array}{l}\mathrm{F}_{0} \text { : Survival, development, and growth in embryo- } \\
\text { Larval stages }\end{array}$ \\
\hline 56 & $\begin{array}{l}F_{0}: \text { Survival, development, growth, and sex ratio in } \\
\text { subadult fish }\end{array}$ \\
\hline 120 & $\begin{array}{l}F_{0} \text { : Breeding pairs established; spare fish used to } \\
\text { assess growth and sex ratio }\end{array}$ \\
\hline $140-300$ & $\begin{array}{l}F_{0}: \text { Spawning by adult pairs and assessment of fe- } \\
\text { cundity and } F_{1} \text { embryo quality }\end{array}$ \\
\hline $160-250$ & $\mathrm{~F}_{1}$ : Embryo development and hatching \\
\hline $160-260$ & $\begin{array}{l}F_{1} \text { : Survival, development, and growth in embryo- } \\
\text { larval stages over } 28 \mathrm{~d} \text { posthatch; sex ratios of } \\
28 \text {-d-old-fish based on histology }\end{array}$ \\
\hline 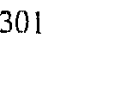 & $\begin{array}{l}F_{0}: \text { Termination of adult fish and assessment of } \\
\text { growth, gross pathology, standard length, wet } \\
\text { weight, residue analysis, and plasma vitellogenin }\end{array}$ \\
\hline
\end{tabular}

